\title{
Karakteristik Fisik Tanah Menurut Tipe Penggunaan Lahan di Negeri Tawiri Sesuai Tata Ruang Kota Ambon
}

\author{
Physical Characteristics of Soil According to Landuse Types of Negeri Tawiri and Ambon's Spatial \\ Planning
}

\section{Parmenas G. Kastanya ${ }^{1}$, Conradus Ufie ${ }^{*, 2}$, Ferad Puturuhu ${ }^{2}$}

${ }^{1}$ Program Studi Agroteknologi, Jurusan Budidaya Pertanian, Fakultas Pertanian, Universitas Pattimura, Jl. Ir. M. Putuhena, Kampus Poka Ambon, 97233

${ }^{2}$ Jurusan Budidaya Pertanian, Fakultas Pertanian, Universitas Pattimura, Jl. Ir. M. Putuhena, Kampus Poka Ambon *E-mail Penulis Korespondensi: ufieconr@gmail.com

\begin{abstract}
This study aims to identify land-use changes and soil physical characteristics and to determine the suitability of present land use in Tawiri to Ambon City Spatial Planning. This research was carried out in the Tawiri Village (Negeri) of Ambon City in June-July 2018 by using a survey method with transect/lane observation distance that was made to cut the types of land use in the area according to Ambon City Spatial Planning. The results of this study are 1) the types of land use found in the five transect lines at Tawiri Village research sites were: secondary dryland forests, mixed dryland agriculture, dryland agriculture, grass/shrubs, settlements, sago, and mangrove areas; 2) physical characteristics of soil and environment showed differences in land use types and soil physical properties, namely: land with altitude \pm 45-335 $\mathrm{m}$ above sea level, hilly/mountainous land forms, hill and mountain reliefs, slopes between $20^{\circ}$ $220^{\circ}(2-25 \%)$, had \pm three layers of soil with varying depths of $0->40 \mathrm{~cm}$; had soil characteristics of $2.5 \mathrm{YR}$ (red) and 7.5 YR (red, reddish yellow, brown to strong brown); textures of clay, clay sand and sandy clay; classified as humid; pH 6-7; and had a distribution of organic materials which varied from low to high; and 3) The actual land use that was the same as that of the spatial designation in Tawiri Village was mostly almost suitable, those who were not suitable were the settlements which were around $78 \%$ in the coastal border.
\end{abstract}

Keywords: characteristics, soil physics, land use

\section{ABSTRAK}

Penelitian ini bertujuan mengidentifikasi perubahan tipe penggunaan lahan dan kondisi karakteristik fisik tanah, dan mengetahui kesesuaian pemanfaatan lahan dengan tata ruang Kota Ambon di wilayah Negeri Tawiri. Penelitian ini dilaksanakan di Negeri Tawiri Kota Ambon pada bulan Juni-Juli 2018 dengan menggunakan metode survei dengan jarak observasi transek/jalur dibuat memotong tipe-tipe penggunan lahan dalam kawasan sesuai arahan Tata Ruang Kota Ambon. Hasil penelitian ini yaitu: 1) Tipe penggunaan lahan yang ditemukan pada lima jalur transek di lokasi penelitian Negeri Tawiri adalah: hutan lahan kering sekunder, pertanian lahan kering campuran, pertanian lahan kering, rumput/semak belukar, permukiman, sagu, dan mangrove; 2) Karakteristik fisik tanah dan lingkungan menunjukkan perbedaan pada tipe penggunaan lahan dan sifat fisik tanah yaitu: tanah dengan ketinggian tempat \pm 45-335 m dpl, bentuk lahan perbukitan/pegunungan, relief bukit dan gunung, lereng antara $20^{\circ}-220^{\circ}(2-25 \%)$, memiliki \pm 3 lapisan tanah dengan kedalaman bervariasi antara $0->40 \mathrm{~cm}$; memiliki ciri tanah: warna 2,5 YR (merah) dan 7,5 YR (merah, kuning kemerahan, cokelat hingga cokelat kuat); tekstur lempung, pasir berlempung dan lempung liat berpasir; tergolong lembab; pH 6-7; dan memiliki sebaran BO yang bervariasi dari sedikit hingga banyak; dan 3) Penggunaan lahan aktual yang sama dengan peruntukan tata ruang di Negeri Tawiri hampir sebagian besar sesuai, yang tidak sesuai hanyalah permukiman yang berada sekitar $78 \%$ di sempadan pantai.

Kata kunci: fisik tanah, karakteristik, penggunaan lahan

\section{PENDAHULUAN}

Tanah adalah kumpulan dari benda alam di permukaan bumi yang tersusun dalam horison-horison, terdiri dari campuran bahan mineral, bahan organik, air dan udara, dan merupakan media untuk tumbuhnya tanaman (Hardjowigeno, 1995). Tanah secara alami merupakan bagian dari lahan sehingga segala sesuatu 
yang terjadi pada lahan (tipe penggunaan lahan) berpengaruh langsung terhadap karakteristik tanah. Lahan dapat diartikan sebagai lingkungan fisik yang terdiri atas iklim, relief, tanah, air dan vegetasi serta benda yang ada diatasnya sepanjang ada pengaruhnya terhadap penggunaan lahan (Sitorus, 2004). Lahan merupakan suatu daerah di permukaan bumi dengan sifat-sifat tertentu yang meliputi biosfer, atmosfer, tanah, lapisan geologi, hidrologi, populasi tanaman, binatang dan hasil kegiatan manusia masa lalu dan masa sekarang sampai pada tingkat tertentu. Sifat-sifat tersebut mempunyai pengaruh yang berarti terhadap penggunaan lahan oleh manusia pada masa sekarang dan masa yang akan datang (FAO, 1976 dalam Kusrini et al., 2011). Jadi penggunaan lahan (land use) berkaitan dengan kegiatan manusia pada bidang lahan tertentu (Buono et al., 2004; Sari, 2015).

Menurut Sandy (1995), penggunaan lahan merupakan wujud dari kegiatan manusia pada suatu ruang atau tanah. Sementara menurut Purwadhi (2008), penggunaan lahan berkaitan dengan kegiatan manusia pada bidang lahan tertentu, penggunaan lahan biasanya digunakan untuk mengacu pada pemanfaatan masa kini. Dengan demikian penggunaan lahan dapat diartikan sebagai segala bentuk kegiatan manusia pada bidang lahan yang dilakukan untuk mendapatkan manfaat guna memenuhi kebutuhan hidup (Ismail, 2009).

Penggunaan lahan termasuk tipe-tipe penggunaan lahan yang diatur/ditetapkan secara legal dalam penataan ruang kota yang meliputi wilayah-wilayah desa adalah campur tangan manusia untuk memenuhi kebutuhan baik material maupun spiritual dan lingkungan hidup. Alih fungsi lahan dalam arti perubahan penggunaan lahan pada dasarnya tidak dapat dihindari dalam pelaksanaan pembangunan (Eko dan Rahayu, 2012).

Perkembangan jumlah penduduk yang sangat cepat, mengakibatkan peningkatan kebutuhan hidup, baik secara kuantitas maupun kualitas, sedangkan ketersediaan sumber daya lahan/kawasan, semakin berkurang dan sangat terbatas. Dua hal yang saling bertentangan tersebut akan meningkatkan tekanan terhadap sumber daya lahan. Dipaksa untuk berproduksi setinggi-tingginya, tanpa berpikir akibat yang ditimbulkan, sehingga terjadi perubahan fungsi lahan/kawasan. Perubahan tipe penggunaan lahan hutan menjadi tipe penggunaan lahan pertanian dan pemukiman atau industri, tentu membawa perubahan terhadap fungsi hutan dan tata air (keseimbangan infiltrasi dan run off) secara cepat terutama pada pulau kecil dengan dataran pesisir yang sempit. Perubahan fungsi hutan dan tata air pada dataran pesisir tersebut, berpengaruh langsung terhadap karakteristik tanah baik fisik seperti kedangkalan tanah, kelengkapan susunan horison, struktur dan porositas, maupun karakteristik biologi (bahan organik, perakaran, organisme) dan kimia tanah serta lingkungan pesisir secara simultan dan holistik. Untuk Kepulauan Maluku umumnya, dan pulau Ambon khususnya, alih fungsi lahan hutan menjadi lahan pertanian, bukanlah pertanian monokultur tetapi sistem multikultur/polikultur (suatu kearifan lokal) yang juga disebut agroforestry atau sistem dusung termasuk di dalamnya pekarangan pada pemukiman, sehingga dapat saja menahan laju perubahan karakteristik fisik tanah dan lingkungan pesisir umumnya.

Fenomena tersebut dapat ditelusuri pada alih fungsi tipe penggunaan lahan di Negeri Tawiri, Kecamatan Teluk Ambon, yang cenderung bergeser atau tidak sesuai dengan arahan Tata Ruang Kota Ambon tahun 2011-2031, contohnya, lahan hutan sagu beralih menjadi lahan pertanian hortikultura (kebun sayuran), perluasan pemukiman masyarakat dan pembangunan perumahan BTN, serta pembangunan Pangkalan Angkatan Laut dan ruko-ruko (tempat jualan). Laju peralihan tipe penggunaan lahan ini berlangsung cepat dengan berbagai dampak negatif mulai dari wilayah berhutan yang ada di perbukitan atau pegunungan sampai dataran yang ditempati pemukiman yang berada pada wilayah pesisir pantai. Dalam rangka mengendalikan rencana penggunaan lahan dan realitas alih fungsi tipe penggunaan lahan yang keliru (degradatif) menuju kepada rencana penggunaan lahan yang adaptif dan berkelanjutan (sustainable development) untuk Negeri Tawiri ke depan, maka data dan informasi terkait perubahan ini sangat penting.

Dari gambaran diatas, dapat dirumuskan masalah di lokasi adalah penggunaan lahan di Negeri Tawiri saat ini sudah mengalami perubahan, dan tidak sejalan dengan tata ruang Kota Ambon, sehingga perlu mengidentifikasi perbedaan karakteristik fisik tanah dan lingkungan akibat perubahan tipe penggunaan lahan yang terjadi di Negeri Tawiri, serta sejauh mana kesesuaian arahan pemanfaatan lahan tata ruang Kota Ambon terimplementasi di Negeri Tawiri. Berdasarkan rumusan masalah penelitian, maka tujuan dari penelitian ini adalah: 1) mengidentifikasi perubahan tipe penggunaan lahan saat ini pada wilayah petuanan Negeri Tawiri; 2) mendeskripsi kondisi karakteristik fisik tanah dan lingkungan pada tipe penggunaan lahan yang berbeda saat ini; 3) mengevaluasi kesesuaian penggunaan lahan di Negeri Tawiri dengan Tata Ruang Kota Ambon dan dampaknya terhadap karakteristik fisik tanah.

\section{METODE PENELITIAN}

Penelitian dilakanakan di Negeri Tawiri, Kecamatan Teluk Ambon pada Juni-Juli 2018. Alat dan bahan yang digunakan dalam penelitian di lapangan adalah Peta Penggunaan Lahan hasil interpretasi Citra Landsat tahun 2017, Peta Rupa Bumi Indonesia (RBI) dengan skala 1: 50.000, Peta Administrasi Negeri Tawiri, Peta Tata Ruang Kota Ambon 2011-2031, buku munsel soil colour chart, aquades, larutan $\mathrm{HCl}, \mathrm{H}_{2} \mathrm{O}_{2}$, kartu deskripsi boring, buku pedoman pengamatan tanah, perlengkapan tulis-menulis, GPS, kompas, abneylevel, altimeter, meter, parang, pisau lapang, dan bor.

Penelitian ini menggunakan metode survei dengan jarak observasi transek/jalur yang dibuat 
memotong tipe-tipe penggunaan lahan (kawasan) pada peta Tata Ruang Kota Ambon. Pada penelitian ini pengamatan karakteristik fisik tanah lebih difokuskan pada observasi melalui boring mulai dari daerah yang tinggi/bergunung ke daerah yang rendah (pesisir pantai). Kemudian diadakan pengamatan umum tentang jalur transek fenomena/dinamika perubahan penggunaan lahan yang terjadi dan efeknya terhadap kondisi karakteristik fisik tanah dan lingkungan hidup masyarakat setempat (pada samping kiri-kanan jalur).

\section{HASIL DAN PEMBAHASAN}

\section{Lokasi penelitian}

Tawiri merupakan salah satu negeri yang berada pada Kecamatan Teluk Ambon dengan luas wilayah 1987,32 Ha. Secara administrasi Negeri Tawiri berbatasan sebelah Utara dengan Negeri Seith, sebelah Selatan dengan perairan Teluk Ambon, sebelah Barat dengan Negeri Hatu dan Bandara Pattimura, sebelah Timur dengan Negeri Hative Besar. Negeri Tawiri secara Astronomis terletak pada koordinat 3038'20,4" 3041'6,0” LS dan 128040'30,0” - 12807'15.60" BT.

\section{Kondisi lahan}

Bentuk wilayah Negeri Tawiri bervariasi dari dataran, perbukitan dan hingga bergunung. Dataran merupakan wilayah pesisir yang tidak terlalu luas dibandingkan dengan wilayah perbukitan dan bergunung, namun merupakan-tempat tinggal sebagian besar penduduk Negeri Tawiri, kecuali Dusun Batusori dan Dusun Hila Tanah Putih yang menempati daerah perbukitan. Geologi Negeri Tawiri adalah bahan Aluvium dan Andesit, serta Koral yang ditemukan di beberapa tempat dalam jumlah yang sedikit sekali.
Iklim Negeri Tawiri adalah iklim musim yaitu musim Barat atau Utara dan musim Timur atau Tenggara, dan diselingi oleh musim pancaroba yang merupakan transisi dari kedua musim tersebut. Musim Barat umumnya berlangsung dari bulan Desember sampai dengan bulan Maret, sedangkan bulan April merupakan masa transisi ke musim Timur yang berlangsung dari bulan Mei sampai dengan bulan Oktober disusul oleh masa pancaroba pada bulan November.

Total curah hujan rata-rata tahunan adalah 3.915 $\mathrm{mm}$. Curah hujan tertinggi di atas $5.000 \mathrm{~mm}$ terjadi di tahun 2008, 2012 dan 2017. Curah hujan rata-rata bulanan yang sangat tinggi terjadi pada bulan Mei, Juni, dan Juli yaitu masing-masing $571 \mathrm{~mm}, 683,4 \mathrm{~mm}$ dan $805,1 \mathrm{~mm}$. Curah hujan rata-rata terendah terjadi pada bulan November yaitu 77,9 mm. Curah hujan melebihi $1.000 \mathrm{~mm}$ terjadi pada bulan Mei 2011, Juni 2012, 2017, Juli 2012, 2013, 2017, dan Agustus 2008 (Tabel $1)$.

\section{Kondisi sosial}

Jumlah penduduk dan mata pencaharian atau kondisi ekonomi merupakan faktor-faktor dalam menentukan perkembangan dan pertumbuhan penduduk. Total penduduk Negeri Tawiri berjumlah 8.126 jiwa, terdiri dari laki-laki 4.026 jiwa dan perempuan 4.100 jiwa dan jumlah total Kepala Keluarga $2.708 \mathrm{KK}$. Jumlah peduduk munurut mata pecaharian disajikan pada Tabel 2.

Tipe pemanfaatan atau penggunaan lahan yang terdapat pada wilayah petuanan Negeri Tawiri terdiri atas dua bagian yaitu, tipe penggunaan lahan yang direncanakan/ditetapkan dan tipe penggunaan lahan yang dilaksanakan sekarang (present land use).

Tabel 1. Curah hujan bulanan dan tahunan selama 10 tahun (2008-2017)

\begin{tabular}{cccccccccccccc}
\hline Thn & Jan & Feb & Mar & Apr & Mei & Jun & Jul & Ags & Sep & Okt & Nov & Des & Tot \\
\hline 2008 & 252 & 206 & 78 & 271 & 644 & 736 & 894 & 1297 & 769 & 214 & 120 & 229 & 5710 \\
2009 & 191 & 89 & 98 & 115 & 359 & 229 & 333 & 79 & 135 & 192 & 80 & 110 & 2010 \\
2010 & 166 & 32 & 109 & 113 & 353 & 833 & 736 & 849 & 213 & 106 & 146 & 276 & 3932 \\
2011 & 228 & 202 & 127 & 240 & 1468 & 691 & 694 & 323 & 304 & 143 & 44 & 147 & 4611 \\
2012 & 100 & 119 & 298 & 80 & 908 & 1252 & 1157 & 639 & 254 & 136 & 26 & 79 & 5048 \\
2013 & 252 & 195 & 78 & 167 & 395 & 360 & 1923 & 629 & 360 & 129 & 91 \\
2014 & 305 & 177 & 60 & 154 & 417 & 384 & 226 & 498 & 117 & 129 & 31 \\
2015 & 159 & 196 & 120 & 299 & 181 & 720 & 127 & 70 & 3 & 67 & 15 & 135 \\
2016 & 70 & 37 & 195 & 355 & 239 & 199 & 915 & 347 & 342 & 185 & 37 & 119 \\
2017 & 284 & 152 & 143 & 129 & 751 & 1430 & 1046 & 452 & 501 & 180 & 189 & 36 \\
Tot & 2007 & 1405 & 1306 & 1923 & 5715 & 6834 & 8051 & 5183 & 2998 & 1481 & 779 \\
Rat2 & 167.25 & 117.08 & 188.83 & 160.25 & 476.25 & 569.5 & 670.92 & 431.92 & 249.83 & 123.42 & 64.92 & 122.42 & 529 \\
\hline
\end{tabular}

Sumber: Stasiun Meteorologi Kelas II Patimura Ambon, 2018.

Tipe penggunaan lahan yang direncanakan/ ditetapkan adalah yang ada dalam Rencana Tata Ruang Wilayah (RTRW) Kota Ambon tahun 2011-2031 (Perda Kota Ambon Nomor 24/2012), antara lain: 1) kawasan lindung meliputi: a) hutan lindung dan penyanggah pada puncak/punggung gunung dan lerang tengah yang memberikan perlindungan terhadap kawasan dibawah- nya; b) Rawa sagu dan nipah beserta mangrove (kawasan pantai berhutan bakau) dan sempadan pantai sebagai kawasan perlindungan setempat (sekaligus kawasan rawan bencana pada pulau-pulau kecil dan pesisir), selain kawasan ruang terbuka hujan (RTH); 2) penggunaan atau peruntukan lahan untuk fungsi budidaya meliputi: a) lahan pertanian (kawasan pertanian, 
dan pusat pertanian tanaman pangan); b) lahan permukiman (kawasan permukiman dan perumahan); c) lahan atau kawasan perdagangan dan industri jasa maritime; d) lahan atau kawasan pariwisata selain ruang terbuka non hijau; e) lahan pertambangan bahan galian $\mathrm{C}$; dan $\mathrm{f}$ ) tipe penggunaan atau peruntukan lahan lainnya (seperti sempadan sungai dan sumber air atau rawa/cekungan resapan air). Luasan tipe penggunaan lahan seperti disajikan pada Tabel 3.

Tabel 2. Jumlah penduduk menurut mata pencaharian

\begin{tabular}{clc}
\hline No & Tingkat Pekerjaan & Jumlah Pekerja \\
\hline 1. & Petani & 243 \\
2. & Nelayan & 213 \\
3. & Pegawai Negeri Sipil & 728 \\
4. & Pegawai Swasta & 491 \\
5. & Wiraswasta & 521 \\
6. & Satpam & 359 \\
\multicolumn{2}{c}{ Total } & $\mathbf{2 . 5 5 5}$ \\
\hline
\end{tabular}

Sumber: Kantor Negeri Tawiri tahun 2017

\section{Tipe Penggunaan Lahan Sekarang Pada Petuanan Negeri Tawiri}

Secara legal dan ideal tipe-tipe penggunaan lahan tersebut diupayakan perwujudannya hingga tahun 2031 oleh semua pihak yang terkait di Negeri Tawiri seacara adaptif dan berkelanjutan. Karenanya perlu dilakukan pengkajian guna memetakan dan mengindentifikasi perubahan kondisi tipe-tipe penggunaan lahan saat ini pada lahan atau wilayah petuanan Negeri Tawiri dalam rangka pengawasan publik-akademik terhadap keterlaksanaan penggunaan lahan dan adaptabilitas sustainabilitasnya, seperti ditunjukkan pada Gambar 1.
Tabel 3. Luasan penggunaan lahan di Negeri Tawiri Tahun 2017

\begin{tabular}{clr}
\hline \multirow{2}{*}{ No } & \multicolumn{1}{c}{ Penggunaan Lahan } & \multicolumn{1}{c}{ Luas (Ha) } \\
\cline { 3 - 3 } & Tahun 2017 \\
\hline 1 & Hutan Lahan Kering Sekunder & 1148,18 \\
2 & Pertanian Lahan Kering & 586,62 \\
& Campuran & 10,75 \\
3 & Pertanian Lahan Kering & 73,09 \\
4 & Rumput/Semak Belukar & 153,64 \\
5 & Permukiman & 9,39 \\
6 & Sagu & 3,14 \\
7 & Mangrove & 2,51 \\
8 & Non PL & $\mathbf{1 9 8 7 , 3 2}$ \\
\hline \multicolumn{2}{c}{ Total Luas } \\
Sumber: Hasil Interpretasi Citra Landsat 8 OLI (November, \\
\multicolumn{2}{c}{ 2017) }
\end{tabular}

Berdasarkan Gambar 1, diketahui bahwa dalam kurun waktu \pm 1 tahun, telah terjadi penurunan luas penggunaan lahan sagu sebesar 1,17 $\mathrm{Ha}$, dan bertambahnya luas lahan pertanian lahan kering dari 4,91 Ha menjadi 6,19 $\mathrm{Ha}$ (meningkat 1,28 Ha).

Perubahan tipe penggunaan lahan pada prinsipnya terkait dengan arahan tata ruang wilayah, karena pemanfaatan lahan yang sesuai diharapkan akan memberikan dampak yang baik terhadap pembangunan berkelanjutan/lestari. Walaupun terjadi perubahan penggunaan lahan tapi dihubungkan dengan tata ruang wilayah Kota Ambon perubahan ini tidak mempengaruhi perubahan rencana tata ruang Kota Ambon yang ada di Negeri Tawiri, seperti disajikan pada Gambar 2.

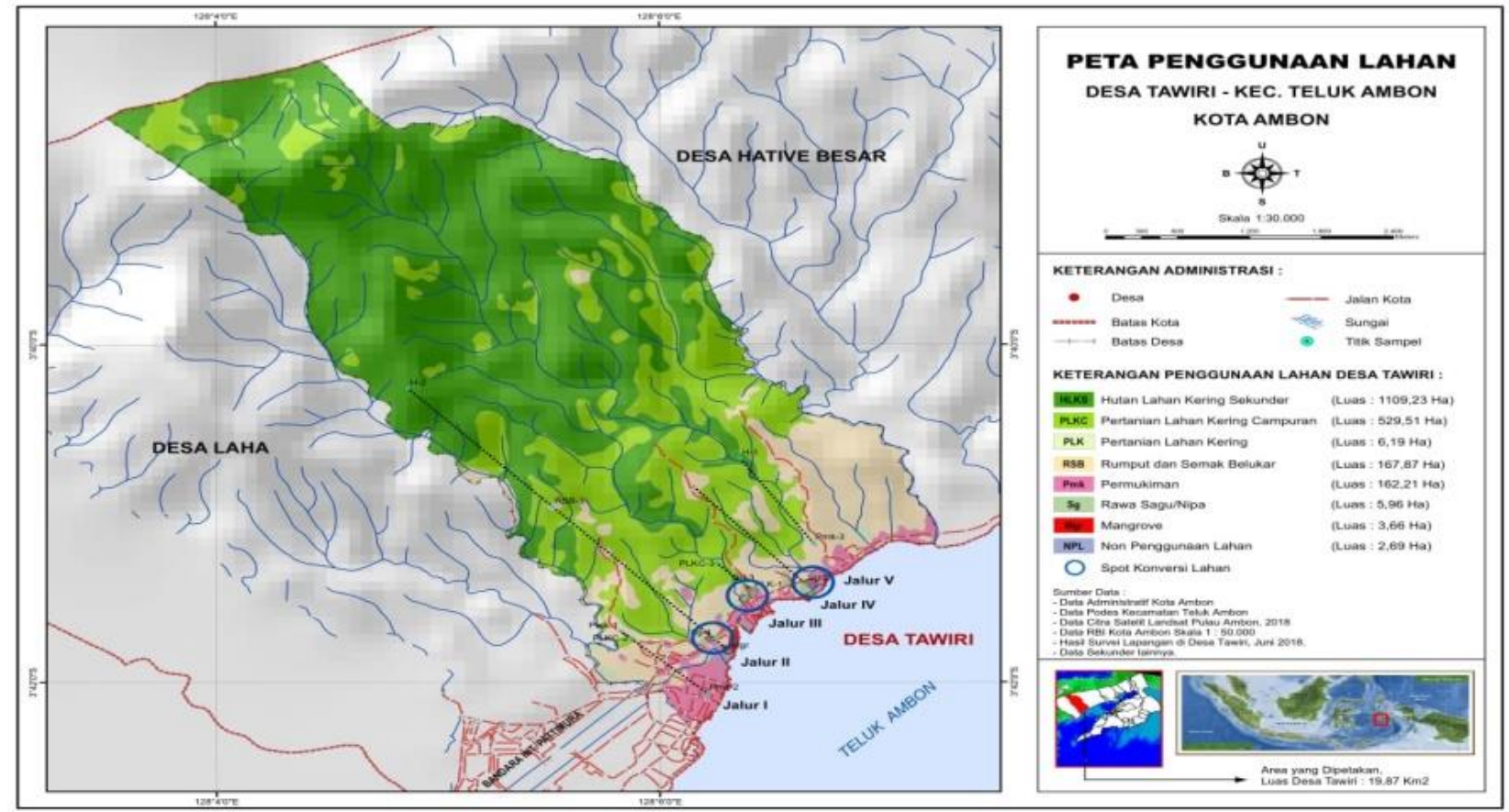

Gambar 1. Peta penggunaan lahan tahun 2018 (Update Nov. 2017) 
Gambar 2, menunjukkan tipe penggunaan lahan sekarangdi lokasi studi, dan perubahannya terhadap RTRW Kota Ambon 2011-20131. Perubahan tipe penggunaan lahan tersebut dapat diuraikan sebagai berikut:

a. Penggunaan lahan untuk fungsi kawasan lindung atau pengamanan meliputi Kawasan Hutan Lindung (HL) terjadi perubahan penggunaan lahan dari hutan menjadi pertanian lahan kering campuran seluas 64,75 Ha; Kawasan Pantai Berhutan Bakau (PHB) terjadi perubahan penggunaan lahan dari mangrove dan rawa sagu menjadi permukiman seluas 5,83 Ha; Kawasan Penyangga (PYG) terjadi perubahan penggunaan lahan dari hutan dan rumput dan semak menjadi pertanian lahan kering seluas 208,59 Ha; Kawasan Sempadan Pantai (SP) terjadi perubahan penggunaan lahan dari mangrove, rawa sagu/nipah dan rumput/semak belukar menjadi permukiman seluas 16,84 Ha dan pertanian lahan kering 0,01 Ha.

b. Penggunaan lahan untuk fungsi kawasan Budidaya meliputi Kawasan Permukiman Kepadatan Sedang (PKS) terjadi perubahan penggunaan lahan di luar kawasan (rawa sagu) menjadi permukiman seluas 1,08 Ha; Kawasan Pertanian (Pt) terjadi perubahan penggunaan lahan hutan dan semak/belukar menjadi pertanian lahan kering campuran seluas $148,10 \mathrm{Ha}$ c. Pada kawasan budidaya, evolusi penggunaan lahan berdasarkan hasil wawancara dengan masyarakat setempat, penggunaan lahan sekarang seperti kawasan permukiman yang terdiri dari pangkalan TNI Angkatan Laut pada tahun-tahun sebelumnya adalah kawasan Dok Tawiri, dan pernah menjadi hutan pantai. Perumahan BTN sebelumnya adalah penggunaan lahan nipah dan sagu, serta pertanian lahan kering. Ruko yang ada diseputaran Dusun Air Bak sebelumnya adalah penggunaan lahan rawa. Penggunaan lahan pertanian lahan kering yang ada di Dusun Wesa sebelumnya adalah penggunaan lahan nipah, sagu, semak belukar.

\section{Kondisi Karakteristik Fisik Tanah Dan Lingkungan Pada Berbagai Tipe Penggunaan Lahan}

Kondisi karakteristik fisik tanah dan lingkungan sangat terkait erat dengan kualitas dan potensi kemampuan serta produktivitas yang dimiliki tanah. Karakteristik fisik tanah yang diteliti meliputi kondisi umum topografi, lereng, ketinggian tempat, relief, dan penggunaan lahan dan karakteristik fisik tanah sendiri adalah kedalaman tanah, warna tanah, tekstur tanah, struktur, kelembaban, $\mathrm{pH}$ dan ketersediaan bahan organik. Berdasarkan hasil penelitian, diperoleh gambaran kondisi umum dan karakteristik fisik tanah pada kelima jalur penelitian seperti urain sebagai berikut:

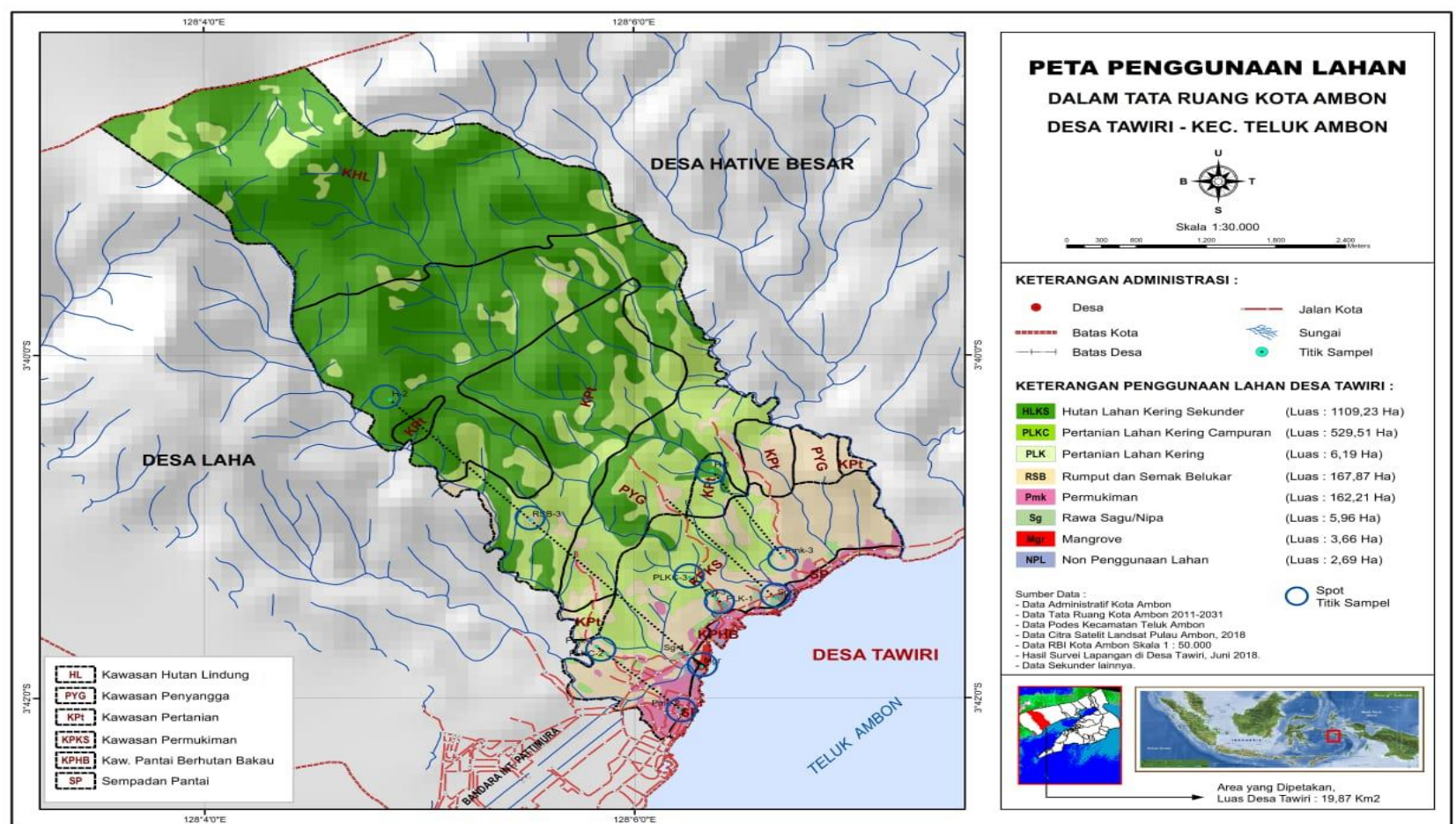

Gambar 2. Peta tipe penggunaan lahan dalam pelaksanaan/implementasi Rencana Tata Ruang Kota Ambon (RTRW 2011-2031) 


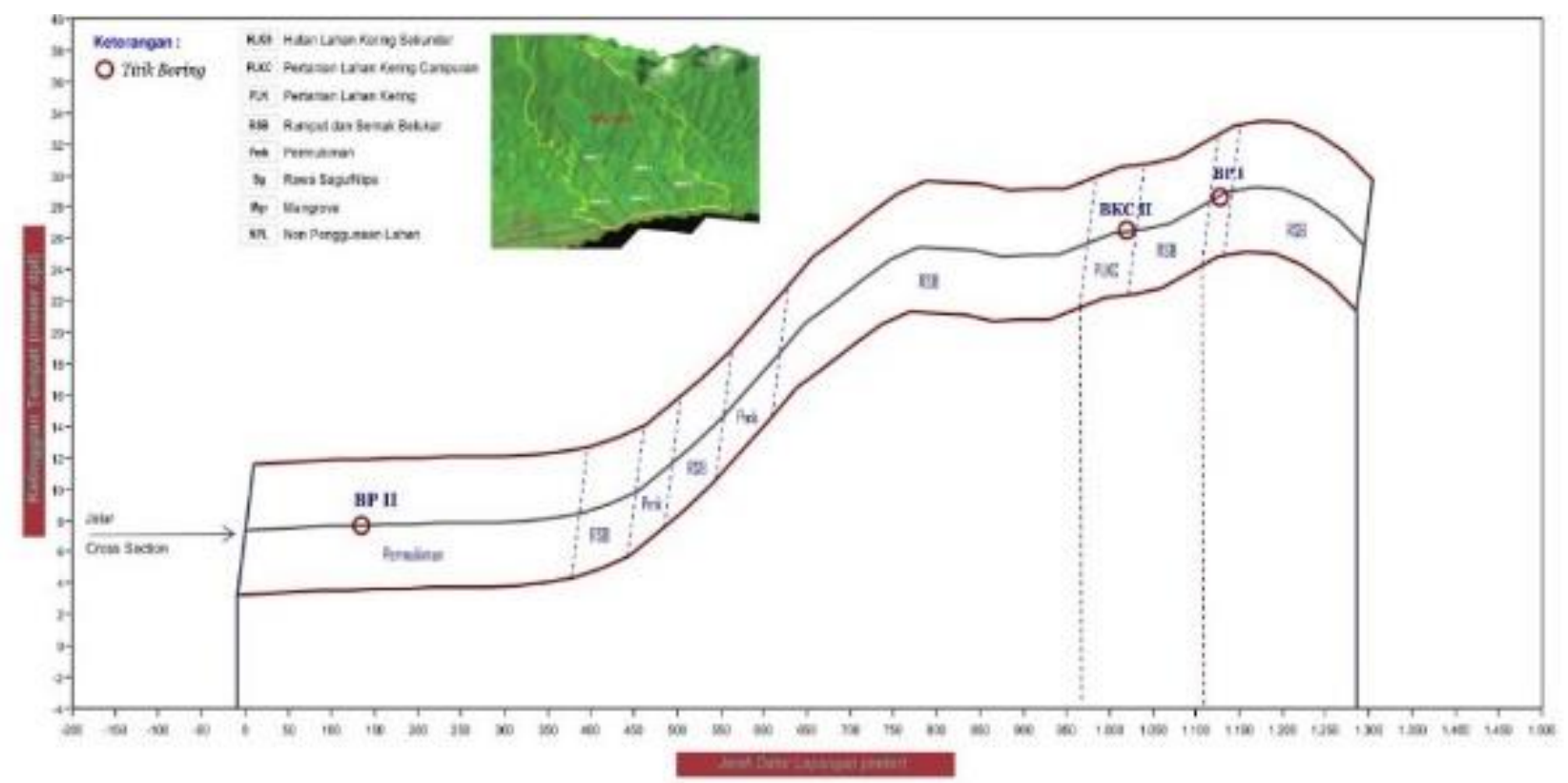

Gambar 3. Penampang melintang pengamatan lapangan di wilayah Negeri Tawiri tahun 2018: Jalur I

Jalur I ditemukan tiga tipe penggunaan lahan yaitu penggunaan lahan pemukiman, rumput dan semak belukar, pertanian lahan kering campuran/kebun campuran. Tanah pada titik 1 permukiman mempunyai enam lapisan dengan kedalaman dari 0->94 cm. Pada titik 2 Pertanian Lahan Kering Campuran ditemukan dua lapisan dengan kedalaman dari $0->61 \mathrm{~cm}$, dan titik 3 (permukiman) ditemukan tiga lapisan dengan kedalaman dari 0->8 cm. Gambaran penampang melintang (cross section) dari jalur I dapat dilihat pada Gambar 3.
Jalur II ditemukan lima penggunaan lahan yaitu penggunaan lahan mangrove, rumput dan semak belukar, pemukiman, sagu, pertanian lahan kering campuran/kebun campuran, dan hutan lahan kering sekunder. Hasil boring tanah menunjukan pada titik 1 Mangrove ditemukan tiga lapisan dengan kedalaman dari 0->67 cm, titik 2 Rumput/Semak Belukar ditemukan dua lapisan dengan kedalaman dari 0->13 cm, titik 3 Hutan Lahan Kering Sekunder ditemukan tiga lapisan dengan kedalaman dari 0->40 cm. Gambaran penampang melintang (cross section) dari jalur II dapat dilihat pada Gambar 4.

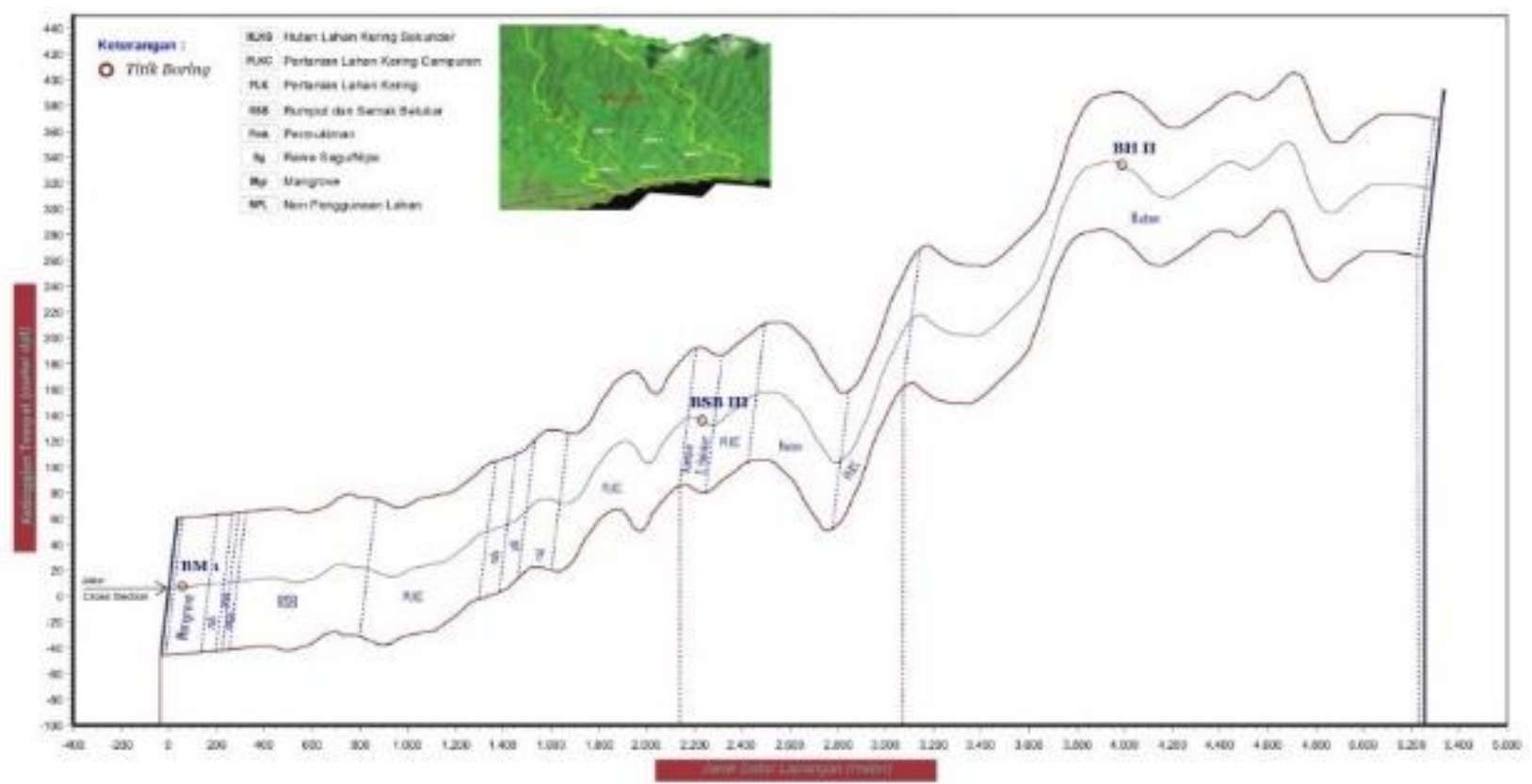

Gambar 4. Penampang melintang pengamatan lapangan di wilayah Negeri Tawiri tahun 2018: Jalur II 
Jalur III ditemukan lima tipe penggunaan lahan yaitu pemukiman, pertanian lahan kering, rumput dan semak belukar, sagu, dan pertanian lahan kering campuran/kebun campuran. Hasil boring menunjukan pada titik 1 Pertanian Lahan Kering ditemukan lima lapisan dengan kedalaman dari $0->85 \mathrm{~cm}$, titik 2 Sagu ditemukan tiga lapisan dengan kedalaman dari 0->34,5 $\mathrm{cm}$, dan titik 3 Pertanian Lahan Kering Campuran ditemukan tiga lapisan dengan kedalaman dari 0->42 $\mathrm{cm}$. Gambaran penampang melintang (cross section) dari jalur III dapat dilihat pada Gambar 5.

Jalur IV ditemukan 3 tipe penggunaan lahan yaitu sagu, rumput dan semak belukar, pertanian lahan kering campuran/kebun campuran. Hasil boring tanah menunjukan pada titik 1 Sagu ditemukan tiga lapisan dengan kedalaman dari 0->44 cm. Gambaran penampang melintang (cross section) dari jalur IV dapat dilihat pada Gambar 6.

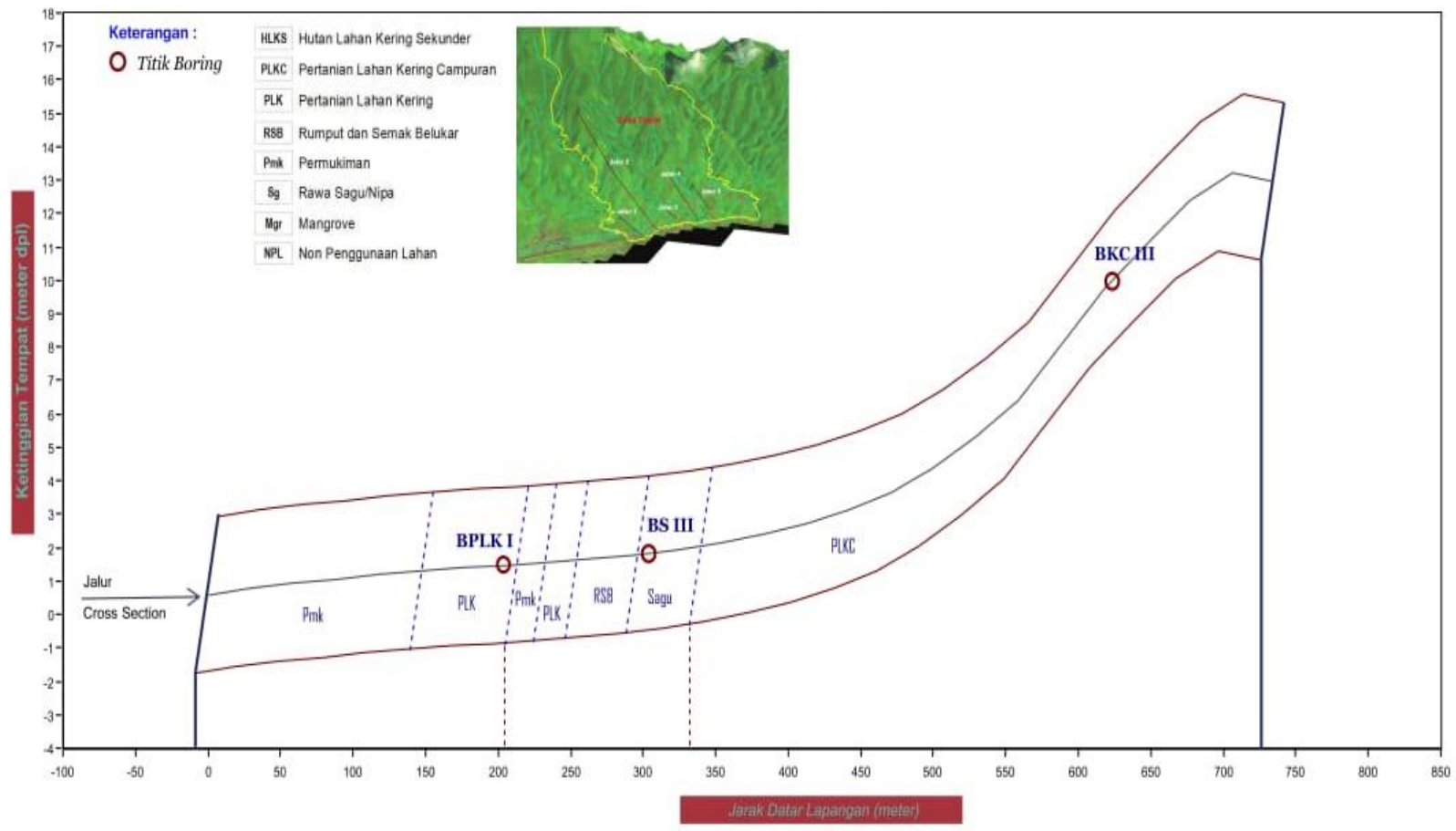

Gambar 5. Penampang melintang pengamatan lapangan di wilayah Negeri Tawiri tahun 2018: Jalur III

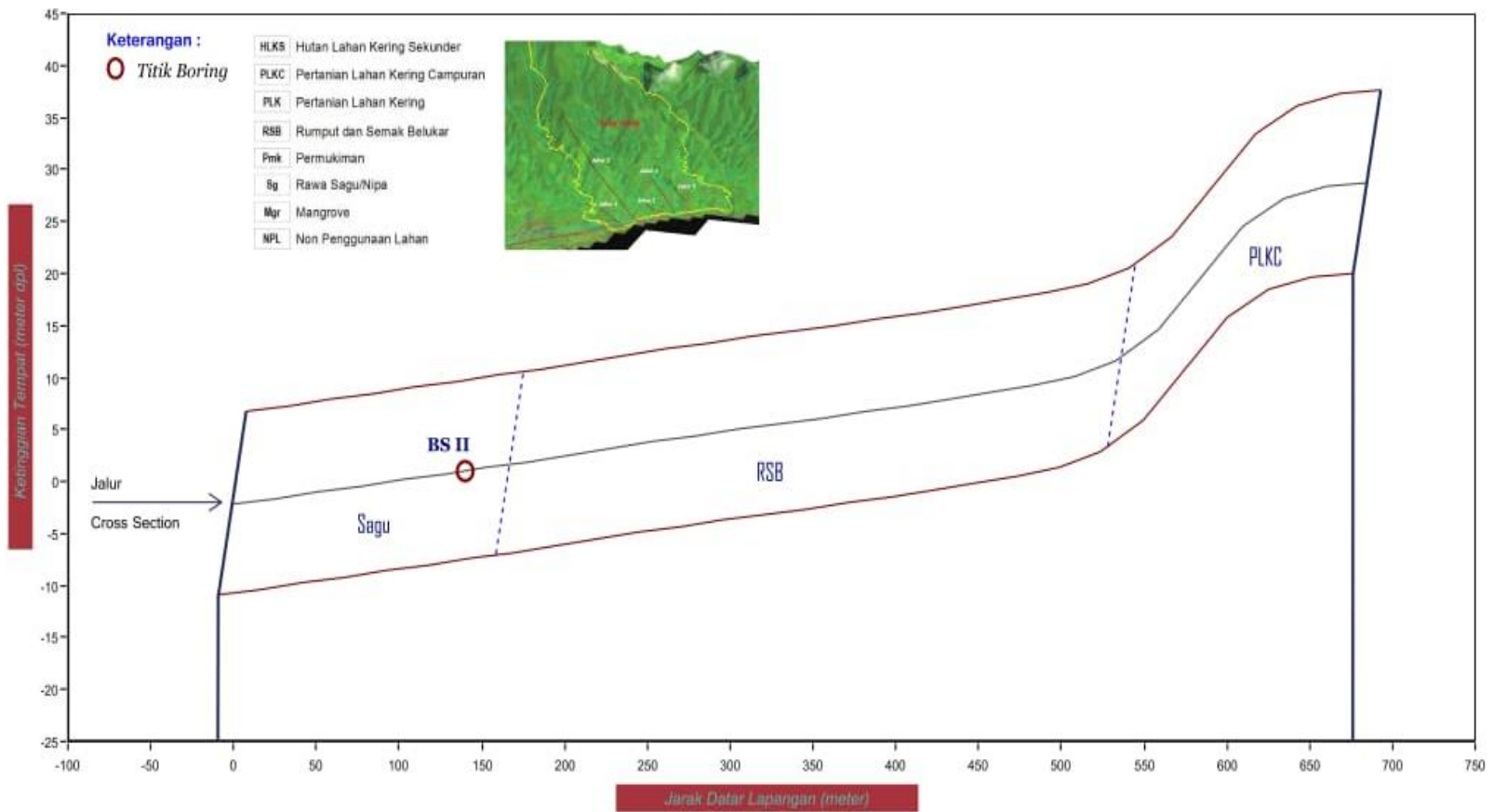

Gambar 6. Penampang melintang pengamatan lapangan di wilayah Negeri Tawiri tahun 2018: Jalur IV 


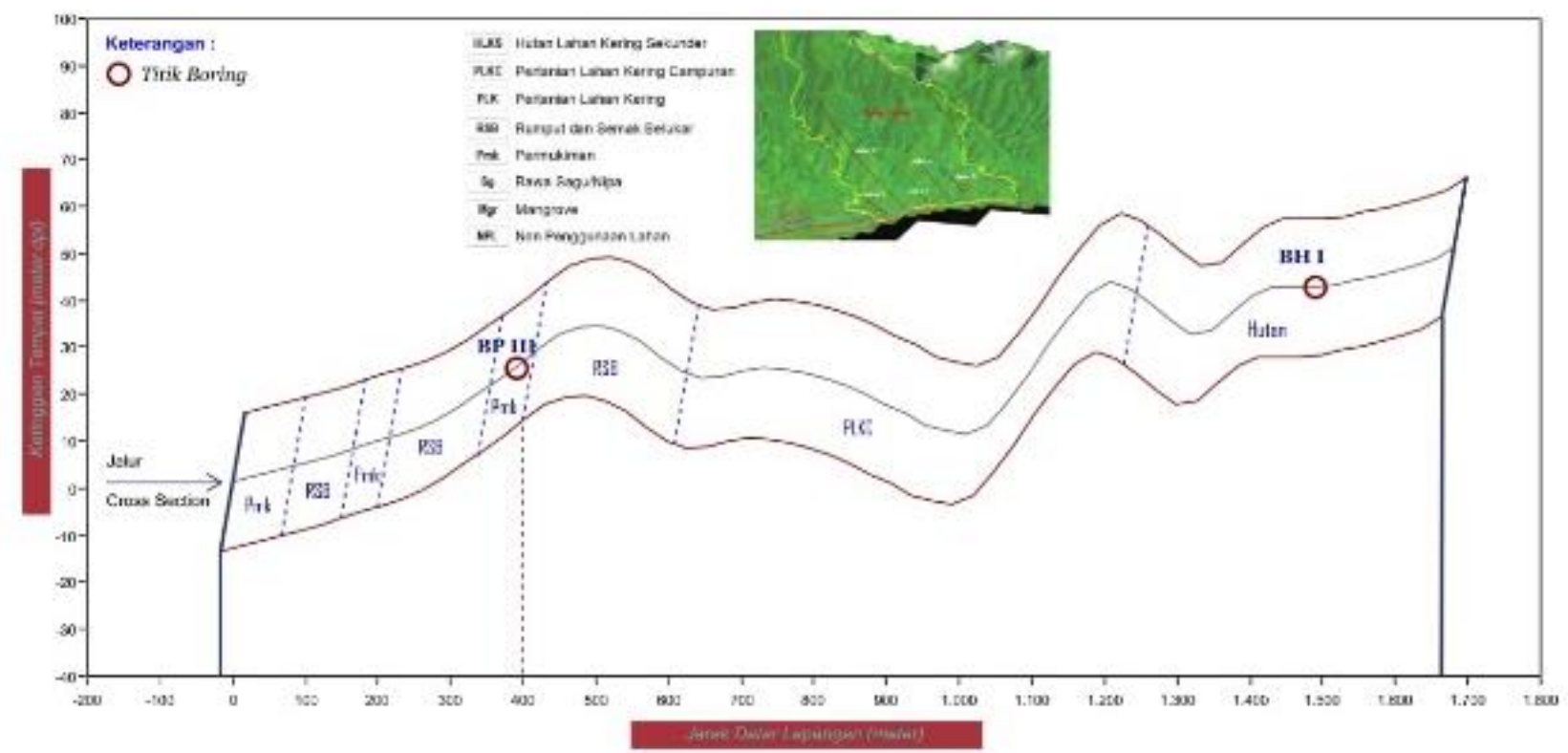

Gambar 7. Penampang melintang pengamatan lapangan di wilayah Negeri Tawiri Tahun 2018: Jalur V

Jalur $\mathbf{V}$ ditemukan beberapa penggunaan lahan seperti pemukiman, rumput dan semak belukar, pertanian lahan kering campuran, dan hutan. Hasil boring tanah menunjukan pada titik 1 Permukiman ditemukan tiga lapisan dengan kedalaman dari $0->27 \mathrm{~cm}$, dan titik 2 Hutan Lahan Kering Sekunder ditemukan tiga lapisan dengan kedalaman dari 0->36 cm. Gambaran penampang melintang (cross section) dari jalur $\mathrm{V}$ dapat dilihat pada Gambar 7.

Berdasarkan hasil deskripsi sifat fisik tanah melalui pengamatan boring, terdapat beberapa perbedaan tipe penggunaan lahan dengan karakteristik fisik tanah dan lingkungan yang ditemukan. Darmawijaya (1990) mengatakan bahwa sifat fisik dan lingkungan (biofisik) yang dipengaruhi oleh penggunaan lahan adalah: kandungan bahan organik, porositas, perakaran, drainase, warna dan kepadatan tanah. Deskripsi perbedaan tipe penggunaan lahan dan sifat fisik tanah ini disajikan secara ringkas pada Tabel 4.

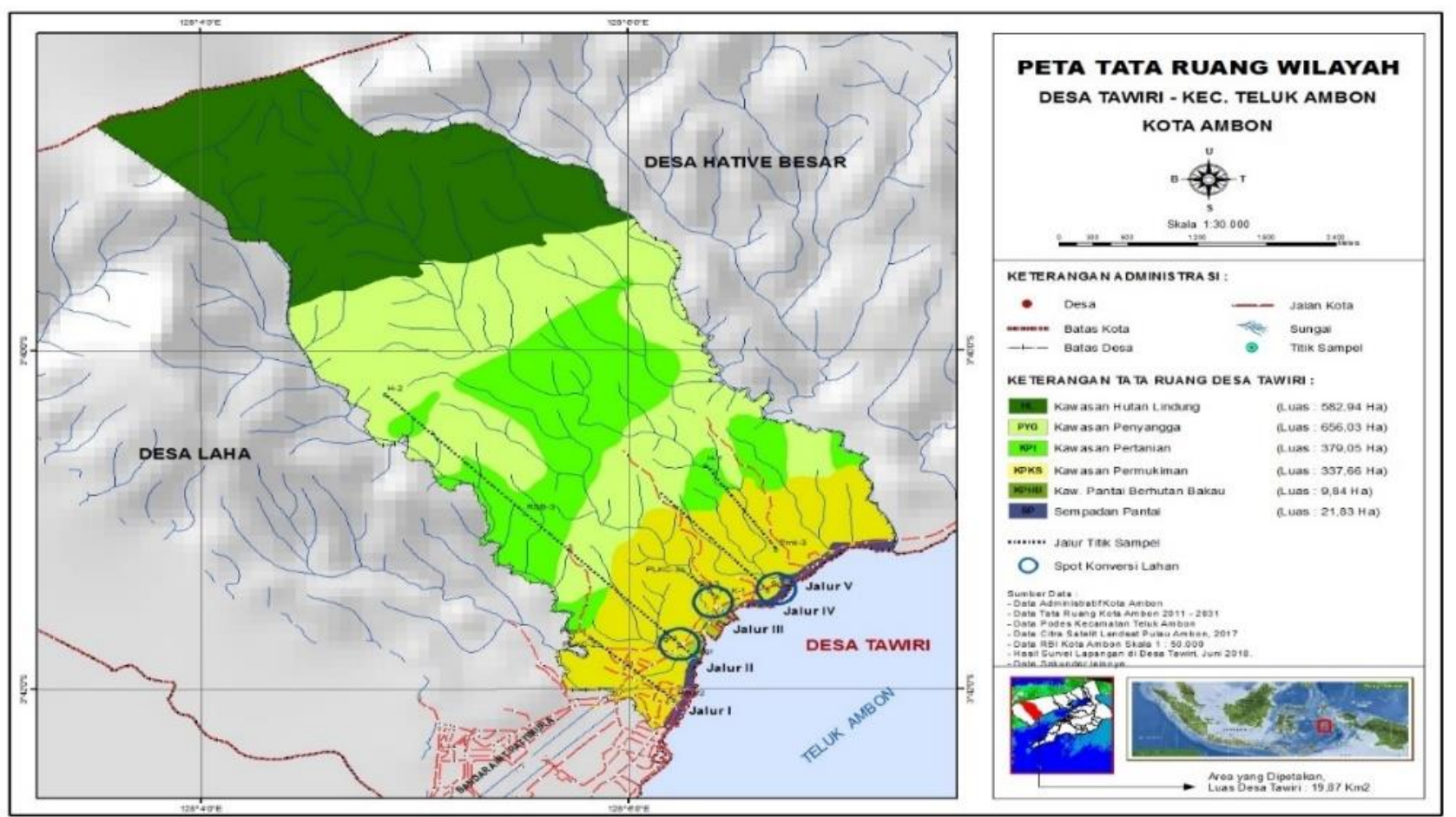

Gambar 8. Penempatan jalur pengamatan pada peta tata ruang wilayah Negeri Tawiri Tahun 2011-2031 
Tabel 4. Karakteristik sifat fisik tanah dan deskripsi tipe penggunaan lahan

\begin{tabular}{|c|c|c|c|c|c|c|c|c|}
\hline \multirow{2}{*}{$\begin{array}{l}\text { Ja- } \\
\text { lur }\end{array}$} & \multirow{2}{*}{$\begin{array}{c}\text { Titik } \\
\text { sampel }\end{array}$} & \multirow{2}{*}{ Fisiografi } & \multirow{2}{*}{$\begin{array}{c}\text { Penggunaan } \\
\text { Lahan }\end{array}$} & \multicolumn{4}{|c|}{ Karakteristik fisik } & \multirow{2}{*}{ Ket. } \\
\hline & & & & Warna & BO & Tekstur & pH & \\
\hline \multirow[t]{3}{*}{$\mathrm{I}$} & 1 & Dataran & Permukiman & Gelap & $\begin{array}{l}\text { Banyak, } \\
\text { Sedang, } \\
\text { sampai } \\
\text { Sedikit }\end{array}$ & $\begin{array}{l}\text { Pasir berlempung, } \\
\text { Lempung berdebu, } \\
\text { Lempung liat } \\
\text { berdebu, Lempung } \\
\text { liat berpasir, } \\
\text { Lempung berpasi } \\
\text { sampai Pasir } \\
\text { berlempung }\end{array}$ & 7 & Konversi dari sagu \\
\hline & 2 & Perbukitan & $\begin{array}{l}\text { Pertanian } \\
\text { lahan kering } \\
\text { campuran }\end{array}$ & Terang & Sedikit & $\begin{array}{l}\text { Lempung liat } \\
\text { berdebu }\end{array}$ & 5 & $\begin{array}{l}\text { Konversi dari hutan } \\
\text { dan kebun } \\
\text { campuran }\end{array}$ \\
\hline & 3 & Perbukitan & Permukiman & Terang & Sedikit, & Lempung berliat & 5 & $\begin{array}{l}\text { Konversi dari kebun } \\
\text { campuran }\end{array}$ \\
\hline \multirow[t]{3}{*}{ II } & 1 & Dataran & Mangrove & Terang & Sedikit & Pasir & 7 & \\
\hline & 2 & Perbukitan & $\begin{array}{l}\text { Rumput dan } \\
\text { semak belukar }\end{array}$ & Terang & Sedikit & Lempung berdebu & $\begin{array}{c}3 \\
\text { sampai } \\
4\end{array}$ & $\begin{array}{l}\text { Konversi dari hutan } \\
\text { dan kebun } \\
\text { campuran }\end{array}$ \\
\hline & 3 & Gunung & $\begin{array}{l}\text { Hutan LK } \\
\text { Sekunder }\end{array}$ & Gelap & Sedikit & $\begin{array}{l}\text { Lempung liat } \\
\text { berpasir }\end{array}$ & $\begin{array}{c}6 \\
\text { sampai } \\
7\end{array}$ & $\begin{array}{l}\text { Konversi dari hutan } \\
\text { primer }\end{array}$ \\
\hline \multirow[t]{3}{*}{ III } & 1 & Dataran & $\begin{array}{l}\text { Pertanian } \\
\text { lahan kering }\end{array}$ & Gelap & $\begin{array}{l}\text { Banyak, } \\
\text { Sedang, } \\
\text { sampai } \\
\text { Sedikit }\end{array}$ & $\begin{array}{l}\text { Lempung liat } \\
\text { berdebu, }\end{array}$ & 6 & $\begin{array}{l}\text { Konversi dari hutan } \\
\text { sagu }\end{array}$ \\
\hline & 2 & Dataran & Sagu & Terang & $\begin{array}{l}\text { Banyak } \\
\text { sampai } \\
\text { Sedang }\end{array}$ & $\begin{array}{l}\text { Lempung berdebu } \\
\text { sampai Lempung }\end{array}$ & 6 & Mulai dikonversi \\
\hline & 3 & Dataran & $\begin{array}{l}\text { Pertanian } \\
\text { lahan kering } \\
\text { campuran }\end{array}$ & Gelap & $\begin{array}{l}\text { Banyak } \\
\text { sampai } \\
\text { Sedikit }\end{array}$ & Lempung berpasir & 6 & $\begin{array}{l}\text { Konversi dari hutan } \\
\text { dan kebun } \\
\text { campuran }\end{array}$ \\
\hline IV & 1 & Dataran & Sagu & Gelap & $\begin{array}{l}\text { Banyak, } \\
\text { Sedang } \\
\text { sampai } \\
\text { Sedikit }\end{array}$ & Lempung & 6 & \\
\hline \multirow[t]{2}{*}{ V } & 1 & Perbukitan & Permukiman & Terang & Sedikit & $\begin{array}{l}\text { Lempung liat } \\
\text { berpasir sampai } \\
\text { Lempung berliat }\end{array}$ & $\begin{array}{c}5 \\
\text { sampai } \\
6\end{array}$ & $\begin{array}{l}\text { Konversi dari } \\
\text { rumput dan semak } \\
\text { belukar }\end{array}$ \\
\hline & 2 & Perbukitan & $\begin{array}{l}\text { Hutan LK } \\
\text { Sekunder }\end{array}$ & Gelap & Banyak & $\begin{array}{l}\text { Lempung sampai } \\
\text { Pasir berlempung }\end{array}$ & 7 & $\begin{array}{l}\text { Konversi dari hutan } \\
\text { primer }\end{array}$ \\
\hline
\end{tabular}

\section{Kesesuaian Penggunaan Lahan Aktual Dengan Tata Ruang Kota Ambon Berdasarkan Karakteristik Fisik Tanah Di Negeri Tawiri}

Kondisi karakteristik fisik tanah dan lingkungan memiliki hubungan yang erat dengan pembangunan berkelanjutan dan merupakan salah satu dasar penataan ruang suatu wilayah. Pemanfaatan lahan yang sesuai dengan arahan tata ruang, akan memberi dampak pada terciptanya kondisi karakteristik fisik tanah dan lingkungan yang stabil. Berdasarkan hasil pengolahan data (peta tumpang susun penggunaan lahan dan tata ruang wilayah petuanan Negeri Tawiri), diketahui bahwa pada titik-titik pengambilan sampel tanah, penggunaan lahannya ada yang sesuai dengan arahan tata ruang dan ada yang tidak sesuai dengan arahan tata ruang. Gambaran posisi jalur dalam arahan tata ruang petuanan Negeri Tawiri dapat dilihat pada Gambar 8.

Tabel 5, menunjukkan bahwa penggunaan lahan mangrove menempati $24 \%$ tata ruang kawasan pantai, dan sesuai; pada kawasan permukiman kepadatan sedang permukiman menempati $41 \%$, pertanian lahan kering campuran menempati 32\%; pertanian lahan kering dan rawa sagu masing-masing menempati luasan $1 \%$ dan sesuai; pada kawasan pertanian, penggunaan lahan hutan lahan kering sekunder menempati $48 \%$ dan rumput $12 \%$; kawasan penyangga, penggunaan lahan hutan lahan kering sekunder menempati $61 \%$ pada kawasan tersebut dan sesuai; kawasan sempadan pantai, permukiman menempati $78 \%$ dan tidak sesuai, hutan rawa menempati $3 \%$. Karakteristik tanahnya bervariasi berdasarkan tempat terbentuknya yang dipengaruhi faktor dan proses pembentukannya. 
Tabel 5. Hubungan tata ruang, penggunaan lahan, dan sifat fisik tanah

\begin{tabular}{|c|c|c|c|c|c|}
\hline Tata Ruang & & $\mathbf{P L}$ & $\%$ & Karakteristik Fisik Tanah & Ket. \\
\hline $\begin{array}{l}\text { Kawasan Pantai } \\
\text { Berhutan Bakau } \\
\text { (Luas 9,83 Ha) }\end{array}$ & $*$ & $\begin{array}{l}\text { Mangrove } \\
\text { (Luas 2,37 Ha) }\end{array}$ & 24 & $\begin{array}{ll}\text { - } & \text { Kedalaman: } 0 \text { - >67 cm } \\
\text { - } & \text { Warna: Merah kekuningan sampai Coklat kemerahan gelap } \\
\text { - } & \text { Tekstur: Pasir } \\
\text { - } & \text { Konsistensi: Lembab sampai Basah } \\
\text { - } & \text { BO: Sedikit } \\
\text { - } & \text { pH rata-rata: } 7\end{array}$ & Sesuai \\
\hline \multirow[t]{4}{*}{$\begin{array}{l}\text { Kawasan } \\
\text { Permukiman } \\
\text { Kepadatan Sedang } \\
(337,64 \mathrm{Ha})\end{array}$} & $*$ & $\begin{array}{l}\text { Permukiman } \\
(140,6 \mathrm{Ha})\end{array}$ & 41 & $\begin{array}{ll}\text { - } & \text { Kedalaman: } 0 \text { - }>8 \mathrm{~cm} \\
\text { - } & \text { Warna: Coklat kuat sampai Merah } \\
\text { - } & \text { Tekstur: Lempung berliat sampai Lempung liat berdebu } \\
\text { - } & \text { Konsistensi: Lembab } \\
\text { - } & \text { BO: Sedikit } \\
\text { - } & \text { pH rata-rata: } 6 \text { sampai } 7\end{array}$ & $\begin{array}{l}\text { Sesuai/T } \\
\text { idak } \\
\text { sesuai }\end{array}$ \\
\hline & $*$ & $\begin{array}{l}\text { Pertanian } \\
\text { Lahan Kering } \\
\text { Campuran } \\
(108,06 \mathrm{Ha})\end{array}$ & 32 & $\begin{array}{ll}\text { - } & \text { Kedalaman: } 0 \text { - > } 61 \mathrm{~cm} \\
\text { - } & \text { Warna: Coklat kuat sampai Kuning kemerahan } \\
\text { - } & \text { Tekstur: Lempung liat berdebu } \\
\text { - } & \text { Konsistensi: Lembab } \\
\text { - } & \text { BO: Sedikit } \\
\text { - } & \text { pH rata-rata: } 5 \\
& \\
\text { - } & \text { Kedalaman: } 0 \text { - > } 42 \mathrm{~cm} \\
\text { - } & \text { Warna: Coklat kekuningan-kuningan sampai Kuning } \\
& \text { kecoklatan } \\
- & \text { Tekstur: Lempung liat berpasir } \\
- & \text { Konsistensi: Lembab } \\
- & \text { BO: Banyak samapi Sedikit } \\
- & \text { pH rata-rata: } 6\end{array}$ & Sesuai \\
\hline & $*$ & $\begin{array}{l}\text { Pertanian } \\
\text { Lahan Kering } \\
(4,90 \mathrm{Ha})\end{array}$ & 1 & $\begin{array}{ll}\text { - } & \text { Kedalaman: } 0 \text { - > } 85 \mathrm{~cm} \\
\text { - } & \text { Warna: Coklat kemerahan gelap, Coklat, Coklat kekuingan, } \\
\text { Coklat kuning-kekuningan muda sampai Abu-abu kecoklatan } \\
\text { muda } \\
\text { - } \quad \text { Tekstur: Lempung liat berdebu } \\
\text { - } & \text { Konsistensi: Lembab samapi Basah } \\
\text { - } & \text { BO: Banyak, Sedang sampai Sedikit } \\
\text { - } & \text { pH rata-rata: } 6\end{array}$ & Sesuai \\
\hline & $\star$ & $\begin{array}{l}\text { Rawa Sagu } \\
(4,03 \mathrm{Ha})\end{array}$ & 1 & $\begin{array}{ll}\text { - } & \text { Kedalaman: } 0 \text { - > } 34,5 \mathrm{~cm} \\
\text { - } & \text { Warna: Hijau lumut, Abu-abu sangat gelap sampai Abu-abu } \\
\text { - } & \text { Tekstur: Lempung berdebu sampai Lempung } \\
\text { - } & \text { Konsistensi: Lembab sampai Basah } \\
\text { - } & \text { BO: Banyak samapi Sedang } \\
\text { - } & \text { pH rata-rata: } 6\end{array}$ & Sesuai \\
\hline \multirow[t]{2}{*}{$\begin{array}{l}\text { Kawasan } \\
\text { Pertanian } \\
(379,04 \mathrm{Ha})\end{array}$} & $*$ & $\begin{array}{l}\text { Hutan Lahan } \\
\text { Kering } \\
\text { Sekunder } \\
(184,16 \mathrm{Ha})\end{array}$ & 48 & $\begin{array}{ll}\text { - } & \text { Kedalaman: } 0 \text { - > } 36 \mathrm{~cm} \\
\text { - } & \text { Warna: Coklat gelap sampai Kuning kemerahan } \\
\text { - } & \text { Tekstur: Lempung sampai berlempung } \\
\text { - } & \text { Konsistensi: Lembab } \\
\text { - } & \text { BO: Banyak } \\
\text { - } & \text { pH rata-rata: } 7\end{array}$ & Sesuai \\
\hline & $*$ & $\begin{array}{l}\text { Rumput dan } \\
\text { Semak Belukar } \\
(46,78 \mathrm{Ha})\end{array}$ & 12 & $\begin{array}{ll}\text { - } & \text { Kedalaman: } 0 \text { - > } 13 \mathrm{~cm} \\
- & \text { Warna: Merah } \\
- & \text { Tekstur: Lempung berdebu } \\
\text { - } & \text { Konsistensi: Lembab } \\
\text { - } & \text { BO: Sedikit } \\
\text { - } & \text { pH rata-rata: } 3 \text { sampai } 4\end{array}$ & Sesuai \\
\hline $\begin{array}{l}\text { Penyangga } \\
(656,01 \mathrm{Ha})\end{array}$ & $*$ & $\begin{array}{l}\text { Hutan Lahan } \\
\text { Kering } \\
\text { Sekunder } \\
(403,42 \mathrm{Ha})\end{array}$ & 61 & $\begin{array}{ll}\text { - } & \text { Kedalaman: } 0 \text { - > } 40 \mathrm{~cm} \\
\text { - } & \text { Warna: Coklat kuat samapi Merah } \\
\text { - } & \text { Tekstur: Lempung liat berpasir } \\
\text { - } & \text { Konsistensi: Lembab } \\
\text { - } & \text { BO: Sedikit } \\
\text { - } & \text { pH rata-rata: } 6 \text { sampai } 7\end{array}$ & Sesuai \\
\hline
\end{tabular}


Tabel 5. Hubungan tata ruang, penggunaan lahan ... (Lanjutan)

\begin{tabular}{|c|c|c|c|c|c|}
\hline Tata Ruang & & PL & $\%$ & Karakteristik Fisik Tanah & Ket. \\
\hline \multirow[t]{2}{*}{$\begin{array}{l}\text { Sempadan Pantai } \\
(21,82 \mathrm{Ha})\end{array}$} & $\%$ & $\begin{array}{l}\text { Permukiman } \\
(16,93 \mathrm{Ha})\end{array}$ & 78 & $\begin{array}{ll}- & \text { Kedalaman: } 0 \text { - >94 cm } \\
\text { - } & \text { Warna: Coklat gelap, Coklat kuat, Coklat, sampai Abu-abu } \\
\text { sangat gelap } \\
\text { - } \\
\text { Tekstur: Pasir berlempung, Lempung berdebu, Lempung liat } \\
\text { berpasir, sampai Lempung berpasir } \\
\text { - } \quad \text { Konsistensi: Lembab } \\
\text { - } & \text { BO: Banyak, sedang sampai sedikit } \\
\text { - } & \text { pH rata-rata: } 7 \\
- & \text { Kedalaman: } 0 \text { - >27 cm } \\
- & \text { Warna: Coklat kuat, Merah tua sampai Kuning kemerahan } \\
- & \text { Tekstur: Lempung liat berpasir sampai Lempung berliat } \\
- & \text { Konsistensi: Lembab } \\
- & \text { BO: Sedikit } \\
- & \text { pH rata-rata: } 5 \text { sampai } 6\end{array}$ & $\begin{array}{l}\text { Tidak } \\
\text { sesuai }\end{array}$ \\
\hline & 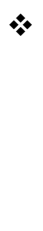 & $\begin{array}{l}\text { Rawa Sagu } \\
(0,70 \mathrm{Ha})\end{array}$ & 3 & $\begin{array}{ll}- & \text { Kedalaman: } 0 \text { - > } 44 \mathrm{~cm} \\
\text { - } & \text { Warna: Coklat sangat gelap sampai coklat kemerahan gelap } \\
\text { - } & \text { Tekstur: Lempung } \\
- & \text { BO: Banyak sampai sedikt } \\
- & \text { Konsistensi: Lembab } \\
- & \text { pH rata-rata: } 6\end{array}$ & Sesuai \\
\hline
\end{tabular}

\section{KESIMPULAN}

Hasil penelitian ini menunjukkan bahwa: 1) Tipe penggunaan lahan yang ditemukan pada lima jalur transek di lokasi penelitian (dari lokasi berlereng/bergunung sampai pantai) Negeri Tawiri adalah: Hutan Lahan Kering Sekunder, Pertanian Lahan Kering Campuran, Pertanian Lahan Kering, Rumput/Semak Belukar, Permukiman, Sagu, dan Mangrove; 2) Karakteristik fisik tanah dan lingkungan menunjukkan perbedaan pada tipe penggunaan lahan dan sifat fisik tanah yaitu: tanah dengan ketinggian tempat antara \pm 45-335 m dpl, bentuk lahan perbukitan/pegunungan, relief bukit dan gunung, lereng antara 200-2200 (2-25\%), memiliki \pm 3 lapisan tanah dengan kedalaman bervariasi antara $0->40 \mathrm{~cm}$, dan memiliki ciri tanah : warna 2,5 YR (merah) dan 7,5 YR (merah, kuning kemerahan, cokelat hingga cokelat kuat); tekstur lempung, pasir berlempung dan lempung liat berpasir; tergolong lembab; $\mathrm{pH}$ 6-7; dan memiliki sebaran BO sedikit hingga banyak dan bahan organik yang bervariasi; dan 3) Penggunaan lahan aktual yang sama dengan peruntukan tata ruang di Negeri Tawiri hampir sebagian besar sesuai, yang tidak sesuai hanyalah permukiman yang berada sekitar $78 \%$ di sempadan pantai.

\section{DAFTAR PUSTAKA}

BAPPEKOT Kota Ambon. 2011. Buku Rencana Tata Ruang Wilayah (RTRW) Kota Ambon Tahun 2011-2031.

Buono, A., Marimin, dan D. Putri. 2004. Klasifikasi Penutup dan Penggunaan Lahan pada
Multispectral Image dari Landsat Thematic Mapper Menggunakan Probabilistic Neural Network. Jurnal Ilmiah-Ilmu Komputer 2: 1-13.

Darmawidjaja, M.I. 1990. Klasifikasi Tanah. Dasar Teori Bagi Peneliti Tanah dan Pelaksana Pertanian di Indonesia. Yogyakarta: Gadjah Mada University Press.

Eko, T. dan S. Rahayu. 2012. Perubahan penggunaan lahan dan kesesuaiannya terhadap RDTR di wilayah peri-urban: studi kasus Kecamatan Mlati. Jurnal Pembangunan Wilayah dan Kota 8: 330-340. DOI: 10.14710/pwk.v8i4.6487

FAO. 1976. A Framework for Land Evaluation for Rainfed Agriculture. Soil Resources Management and Conservation Service Land and Water Development Devision. FAO Soil Buletin No. 52. FAO-UNO, Roma.

Hardjowigeno, S. 1995. Ilmu Tanah. Akademika Presindo, Jakarta.

Ismail, A. 2009. Pengaruh Perubahan Penggunaan Lahan Terhadap Karakteristik Hidrologi Daerah Tangkapan Air Waduk Darma, Kabupaten Kuningan, Provinsi Jawa Barat. Universitas Indonesia, Depok.

Kusrini, Suharyadi, dan S.R. Hardoyo. 2011. Perubahan Penggunaan Lahan dan Faktor yang Mempengaruhinya di Kecamatan Gunung Pati Kota Semarang. Majalah Geografi Indonesia 25: 25-40. DOI: 10.22146/mgi.13358

Perda Kota Ambon. 2012. Peraturan Daerah Kota Ambon Nomor 24 Tahun 2012 tentang Rencana Detail Tata Ruang Wilayah (RTRW) Kota Ambon Tahun 2011-2031. Perda Kota Ambon. 
Purwadhi, F.S.H. dan T.B. Sanjoto. 2008. Pengantar Interpretasi Citra Penginderaan Jauh. Jakarta: Lapan.

Sandy, I.M. 1995. Tanah, Muka Bumi. Indograph Bakti. Sari, S.P. 2015. Identifikasi Karakteristik Dan Pemetaan Tutupan Lahan Menggunakan Citra Lansat 8 (OLI) Di Kabupaten Pesawaran Provinsi Lampung. Departemen Manajemen Hutan, Fakultas Kehutanan. Institut Pertanian Bogor. Bogor.
Siswanto. 2006. Evaluasi Sumbedaya Lahan. Surabaya: UPN PRESS.

Sitorus, J. 2004. Analisis Pola Spasial Penggunaan Lahan Dan Suburbanisasi di Kawasan Jabotabek Periode 1992-2000. Tesis. Sekolah Pascasarjana. Institut Pertanian Bogor. 